\title{
Analysis of the Quality of Life of the Elderly in the Village of Bukit Harapan
}

\author{
Aszrul Ab ${ }^{1}$, Andi Suswani2*, Buharman ${ }^{3}$ \\ Departemen Community and Family Nursing , Stikes Panrita Husada Bulukumba, Indonesia ${ }^{2}$ \\ Departemen Community and Family Nursing, Stikes Panrita Husada Bulukumba ,Indonesia ${ }^{3}$ \\ S1 Nursing Study Program, Stikes Panrita Husada Bulukumba, Indonesia1
}

Corresponding Autor : aderialmakmur@yahoo.co.id*

\begin{abstract}
Quality of life is a person's perception in a cultural context and norms that are relevant to the person's place of life-related to the goals, expectations, standards, and concern for his life. The purpose of this study was to determine the quality of life of the elderly in terms of physical, psychological, level of independence, social, environmental, spiritual life in Bukit Harapan Village in 2018. This study uses a descriptive survey method with a "probability sampling" approach. The sample in this study was 78 respondents with a population of 340 determined using a sampling technique. Data collection was carried out using a questionnaire sheet (check sheet). The analysis used is a univariate analysis which is seen from the results of the frequency distribution. The study showed that the quality of life of the elderly is good as much as $75.3 \%$ and the quality of life that is less than good $25.3 \%$. While seen from the physical domain of the good old $70.1 \%$ the physical is not good $29.9 \%$. while the good psychology domain elderly $67.6 \%$ less good psychological $32.5 \%$. Good independence rate of elderly $71.4 \%$ Poor independence rate $28.6 \%$. Elderly good social domain $72.7 \%$ good social domain $27.3 \%$. The good old neighborhood domain $67.6 \%$ and less good domain $32.5 \%$. Spiritual good $84.4 \%$ Spiritual bad $15.7 \%$. In this study it can be concluded that the quality of life of the elderly from the physical domain that has a less good quality is more than the good, while psychological, independence, social, environmental, spiritual elderly have a good category.
\end{abstract}

\section{Keywords: Quality Of Life, Physical, Psychological, Spiritual}

\section{INTRODUCTION}

Quality of life is one's perception in a cultural context and norms that are relevant to the person's place of life which are related to goals, expectations, standards, and concern for his life. the components contained in the quality of life are physical, psychological, independence, social, environmental, spiritual. Where the quality of a person's life in terms of a broad concept that can be influenced by the individual's physical condition, psychological level of independence, as well as the relationship of individuals with the environment (Samper, Dinatoan, Adi r, Katuuk, \& Mariki e, 2017). In developed countries such as America, it has reached more than 4 million, while in Indonesia with 


\section{COMPRABHANSWE HABH CARE}

the fourth most populated in the world where life expectancy increased from 2004 by 68.6 people in 2015 amounted to 72 million people (Hidayat, 2017).

According to the World Health Organization (WHO), quality of life is an individual's perception in the context of culture and norms following the person's place of liferelated to the goals, expectations, standards, and care of his life. The age limit according to WHO, namely: Elderly includes middle age (middle age), ie the age group of 45 to 59 years, elderly (elderly), between 60 to 74 years, elderly (aged), between 75 to 90 years, very old age (very old), 90 years old. The components contained in the quality of life include physical, psychological, social, environmental (Sudharma \& Salim, 2013). The United Nations Department of Economics and Social Affairs Population Division in 2015 stated that the proportion of elderly globally will increase by more than $4 \%$ over the next 15 years with a population of 60 years old in 2015-2030 predicted to increase by $56 \%$ from 901 million elderly population to 1.4 billion. In line with increasing age, they will experience degenerative both in terms of physical and mental aspects. While the percentage in Indonesia based on prediction results in $2010-2030$ of $10 \%$ will be aged 60 years and over in 2020 (Mawengkang, Sekeon, \& Kaunang, 2017).

Judging from the distribution of the elderly population by province in Indonesia, the percentage of the elderly population is above $10 \%$ while the highest is in the provinces of Yogyakarta (13, 04\%), East Java (10,40\%), Central Java (10, 34\%), Bali (9, 78\%), North Sulawesi $(8,45 \%)$, and South Sulawesi (8, 34\%). Based on data obtained from the Data and Information Center of the Ministry of Health 2013, South Sulawesi Province ranks fifth as the province with the number of $8,34 \%$, the lowest percentage of elderly people in Indonesia (Arny, 2015). Indonesia is one of the countries entering the era of the aging structured population (aging structured population). Demographically, the elderly in Indonesia are 20, 547.541 million people. And it is estimated that the number of the elderly population in Indonesia in 2020 will reach 28,8 million or between $11 \%$ of the total population of Indonesia. While in 2021 the elderly in Indonesia is estimated to reach 30.1 million people who are ranked 4th in the world after China, India, the United States (Ministry of Health, Republic of Indonesia, 2015).

The number of elderly people in South Sulawesi increased along with the improvement in the health condition of the community. Where the life expectancy in 2014 was higher, reaching 70 years of age. While in 2015 the number of elderly people was poured reaching 1, 893, 900 people (BPS SulSel, 2015). Research center agency 


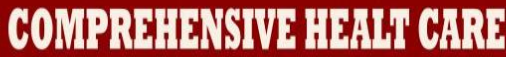

(2015) shows that the number of elderly people in Indonesia reached 20.24 million people and with 8, 03\% of all Indonesian people in 2014 with the number of elderly women as 10, 77 million people and the number of elderly men 9, 47 million inhabitants (Triani, 2017).

Based on data obtained from the Bulukumba district health office in 2017 there were 34, 759 elderly while the data obtained from the Bukit Harapan village office, there were 340 elderly, where there were 161 male elderly, while 179 female elderly were 179. Based on data obtained by researchers on 7 March 2017 in Bukit Harapan Village, there are 6 hamlets. Where Bontonyeleng Hamlet has 72 respondents, Annie Hamlet has 57 respondents, Baji Areng Hamlet has 65 respondents, Bangkeng Buki Hamlet has 60 respondents, Tanjongnge Hamlet has 50 respondents, and Tabbuakang Hamlet has 36 respondents. The number of respondents consisting of 6 hamlets is 340 respondents consisting of the elderly age group that is $45-59$ years, 60-74,

\section{MATERIAL AND METHODS}

Research design is a guide for conducting research, in that it involves a relationship between philosophical assumptions, strategic research strategies and certain methods (Syamsuddin, 2015). This type of research is a descriptive survey research with a "cross-sectional" approach. Cross-sectional research is a type of research that emphasizes the measurement time or survey of independent variable data only once at a time. (Nursalam, 2016). In this type of research, the independent variable is assessed at one time, so there is no further. But the independent variable is assessed only once. With this study, the prevalence or effect of a phenomenon will be obtained (Nursalam, 2016). The population in this study is the elderly aged 45-90 years in Bukit Harapan Village in 2018, amounting to 340 respondents. minimum number of samples in this study as many as 78 respondents.

\section{RESULTS}

Table 1 Distribution of Number of Respondents

\begin{tabular}{lcc}
\hline Gender & $\mathbf{n}$ & Percentage (\%) \\
\hline Male & & 30.8 \\
Female & 24 & 69.2 \\
Age & 54 & \\
$45-59$ Year & & 87.2 \\
$60-74$ year & 68 & 12.8 \\
Level Of Education & 10 & 14.1 \\
Basic Education & & 29.5 \\
Middle eduacation & 11 & 56.4 \\
High Education & 23 &
\end{tabular}




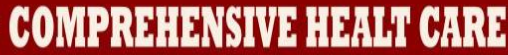

\begin{tabular}{llc} 
Profession & & \\
The Farmer & 24 & 30,8 \\
Housewife & 54 & 69,2 \\
\hline Amount & $\mathbf{7 8}$ & 100 \\
\hline
\end{tabular}

Based on table 1 above shows that of the 78 respondents, based on the characteristics of the distribution of sex the most were female respondents as many as 52 people (67.5), while the least number of respondents were male as many as 26 people (32.6). For the most characteristic of distribution age, the respondents are 55-59 years old with 45 people (71.4), 60-74 years for 23 people (22.1), for the most distribution of educational characteristics, there are 57 elementary school education respondents (74.0), respondents with the lowest level 14 junior high school education (18.2), and at least at the senior high school level of 7 people (7.9) for the characteristics of distribution work, most are respondents with housewife work status as many as 54 people (68.8\%), while the least respondents with 24 farmer status people (31.2\%).

Distribution of the number of respondents based on the quality of life

Tabel 2 Distribusi frekuensi Jumlah Responden Berdasarkan Kualitas Hidup, Fisik,Psikologis, kemandirian, Sosial, lingkungan,Spiritual

\begin{tabular}{lcc}
\hline Quality Of Life & n & Persentage (\%) \\
\hline Good & 37 & 48.7 \\
Not Good & 41 & 51.3 \\
Physical & & \\
Good & 38 & 48.7 \\
Not Good & 40 & 51.3 \\
Psychological & & \\
& & \\
Good & 47 & 60.3 \\
Not Good & 31 & 39.7 \\
Level of Independence & & \\
Good & 44 & 58.4 \\
Not Good & 34 & 43.6 \\
Social & & \\
Good & 47 & 60.3 \\
Not Good & 31 & 39.7 \\
Environment & & \\
Good & 41 & 52.6 \\
Not Good & 37 & 47.4 \\
Spiritual & & \\
Good & 52 & 66.7 \\
Not Good & 26 & 33.3 \\
\hline Amount & 78 & 100.0 \\
\hline \multicolumn{1}{l}{ Based } & (8) & \\
\hline
\end{tabular}

Based on table 2 above, the results of the study showed that of the 78 respondents, the most frequently found was the poor quality of life of 41 people (51.3\%), while the 


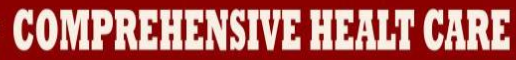

least was the quality of life of 38 students (48.7\%). Based on table 5.3 above, the results of the study show that of the 78 respondents with physical domains, the most frequently found were respondents who had poor physical domains by 40 respondents $(51.3 \%)$, while at least there were physical domains of 38 respondents (48.7\%). The results showed that of the 78 respondents most frequently found were respondents in the good psychological domain by 47 respondents (60.3\%), while the least were respondents in the psychological domain that were less good at 31 respondents (39.7\%). The results showed that of the 78 respondents, most found were respondents in the domain of good independence as many as 44 respondents (58.4\%), while the fewest were respondents who lacked independence as much as 34 respondents (43.6\%). The results showed that of the 78 respondents, the most frequently found respondents with good social as many as 47 respondents (60.3\%), while the least were respondents with poor social as many as 31 respondents (39.7\%). Based on table 5.7 the results of the study show that of the 78 respondents, the most frequently found were respondents with good environment as many as 41 respondents (52.6\%), while the least were respondents with less good environment as many as 37 respondents (47.4\%). The results of this study indicate that of the 78 respondents, the most frequently found were respondents who had good spiritual as many as 52 respondents (66.7\%), while the least were spiritual respondents who were not good as many as 26 respondents (33.3\%).

\section{DISCUSSION}

The quality of life of the elderly in general can be seen from the perception of the life they are experiencing, which is seen from the aspects of general health, physical health, psychological health, independence, social, environmental, spiritual. Good quality of life is obtained from one's good perception of the quality of life of the elderly. The results based on table 5.2 show that of the 78 respondents, the quality of life was 41 respondents (52.6\%) and the quality of life was less than 37 respondents (47.4\%).

This study is in line with the research of Hidayat (2014) which shows that most of the quality of life status of the elderly, the most commonly found is a fairly good quality of life of 77.76, while the quality of life is less good as many as 50 in the working area of the Truck 1 Puskesmas Klaten Regency. The researcher assumes that the quality of life of the elderly can be interpreted as a functional condition of the elderly who is at maximum or optimal conditions so that they can enjoy their old age with meaningful, happy, useful and quality qualities. Physical health becomes an important thing to know 
since physical health is included in the component of a person's quality of life. The quality of life of the elderly can be supported through physical, psychological, independence, social, environmental and spiritual aspects.

The results of the study based on the table show that the physical domain of the elderly in the village of Bukit Harapan most of the physically ill as many as 40 respondents (51.3\%), while the physical domain is good as much as 38 respondents (48.7\%). This study is in line with research conducted by Felce and Ferry (2012) showing that the physical well-being of the elderly is focused on the health of the elderly. The elderly will experience changes in terms of physical, cognitive, and psychological life. While research conducted by (Papalia, Olds, \& Faldman, 2011; Ariyanti, 2013) shows that Optimum aging can be interpreted as a functional condition of the elderly at maximum or optimal conditions so that they can enjoy their old age with meaningful, happy, useful, and quality.

Researchers assume that the physical conditions of the elderly in the hill village of hope most of the elderly have good physical conditions so that they can enjoy their old age with full meaning. The results of the study based on table 5.4 show that the psychological domain of the elderly in the village of Bukit Harapan mostly have good psychological as many as 47 respondents (60.3\%), and the psychological domain is less good as many as 31 respondents (39.7\%). This study is in line with research conducted by Carmody and Beer (2011) showing that those with mindfulness can reduce distress and increase the psychological well-being of the elderly. Mindfulness can balance and enhance the psychological function of the elderly and can accept all changes that occur in his life without overreaction to all physical and psychological changes that occur. Mindfulness elderly will be more sensitive to changes that occur in him, be it changes in thoughts, feelings, and sensation, these changes are not a source of stress, but rather pay attention to the changes that occur.

Researchers assume that most of the elderly feel psychologically needed by the family, can solve problems in various ways, like accepting new ideas, not easily offended, memories are quickly remembered compared to memories of the present, remembering newly placed objects, can start new activities with good, feel not lonely left alone at home, do hobbies or activities, prefer to do something useful outside the home.

The results of the study based on the table show that the psychological domain of the elderly in the village of Bukit Harapan mostly have a good level of independence of 44 


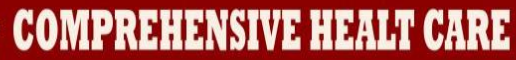

respondents (56.4\%), and a level of independence that is less good as many as 34 respondents (43.6\%). This study is in line with research conducted by Mahoney, F. L and Barthel (2012) which states that to measure the degree of independence of the elderly the Barthel Index is used which includes the ability to eat, the ability to move from the bed, the ability to maintain personal hygiene, wash your face, combing, shaving and brushing teeth, the ability to shower, the ability to walk on a flat road and the ability to go up and downstairs.

Researchers assume that the level of independence can be assessed from the ability of the elderly to carry out an activity without needing help from a good family from the ability to eat, take a bath, move places and help with walking. The results of the study based on table 5.7 show that the elderly environment in the village of Bukit Harapan mostly has a good environment of 41 respondents (52.6\%), and the psychological domain is not good as many as 37 respondents (32,547.4\%). This study is in line with research (Nuryanti, 2012), which states that different domains of residential environment result in changes in the role of the elderly to adjust. For the elderly, the changing roles in the family, social economy and social community lead to setbacks in adapting to their social environment. Researchers assume that the elderly who are in an environment or community level of education and economics who play important roles in meeting the needs of an adequate and adequate environment, including the availability of clean and healthy shelter, and the availability of information related to health services for elderly people in villages.

The results of the study based on table 5.8 show that the majority of respondents have good spiritual as many as 52 respondents (66.7\%). while spiritual is not good as many as 26 respondents (33.3\%). This research is in line with research conducted by (Nugroho, 2013). which states that the spiritual domain includes thinking about the death and life of each person in God's hands, by praying for the courage to endure old age, feeling that without God's help it would not be possible at this age, praying for children and grandchildren to remain in God's protection, if there are problems praying to God, worship at a place of worship. Spiritual development in the elderly that is thinking and acting by giving an example of how to love and justice Krause (2012) in the study findings observed from the effect of attendance on controlled religious services and emotional support found that this helped the elderly to find welfare and purpose in life. Another study shows that older people who attend religious services more often are 
more likely to survive than elderly people who do not go to religious events (Hummer, Rogers, Nam, \& Ellison 2012). Similarly, Krause (2012) argues that greater involvement in religion is also related to the quality of life.

Researchers assume that the involvement of the elderly in spiritual activities has a positive effect on the psychological well-being of the elderly and can survive compared to the elderly who do not go to religious services which are often held in mosques. The elderly often miss opportunities for participation in religious activities that are often held in mosques.

\section{CONCLUSIONS}

Knowing the quality of life of the elderly from the physical aspect, where most of the elderly in the poor category. Knowing the quality of life of the elderly from a psychological aspect where most of the categories are not good. Knowing the quality of life of the elderly from the aspect of independence where most of the categories are not good. Knowing the quality of life of the elderly from social aspects, most of which are in the good category. Knowing the quality of life of the elderly from environmental aspects where most of the good categories. Knowing the quality of life of the elderly from a spiritual aspect where most of the good categories. For families who have the elderly are expected to involve the elderly in family management because it can increase selfesteem in the elderly so that it can improve the quality of life of the elderly.

\section{REFERENCES}

Herawati, Wafroh, S., \& Lestari, D. R. (2016). Dukunga keluarga dengan kualitas Hidup lansia di PSTW budi sejahtera banjarbaru.Dunia Keperawatan, Volume 4, Nomor 1, Maret 2016: 60-64.

Suwarti, d. (2014). Hubungan antara kualitas hidup dengan pengambilan keputusan untuk mengikutu senem prodia pada lansia dalam kelompok prodia purwakerto. psyco idea, Tahun 12. No.2, Juli 2014 ISSN 1693-1076.

Arny. (2015). Hubungan dukungan keluarga dengan kejadian depresi pada lanjut usia di wilaya kerja puskesmas pampang kota makassar.

Kementerian Kesehatan RI. (2015). Data Dan Informasi Tahun 2014 (Profil Kesehatan Indonesia). Diakses melalui http://www.depkes.go.id/resources/download/pusdatin/profil-kesehatanindonesia/profil-kesehatan-indonesia-2014.pdf pada tanggal 13 Januari 2015.

Destiwati, f. (2016). Gambaran kualitas hidup lanjut usia dengan masalah pruritus sinilis di panti sisial tresna warda (pstw) budhi mulia 3 margaguba jakarta selatan. ciputat juni 2016. 


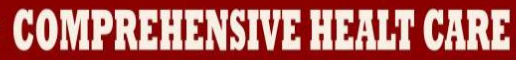

Firmansyah, I. (2014). Hubungan tingkat depresi dengan kualitas hidup pada lansia di kelurahan jember kidul kecematan kaliwates kabupaten jember.Artikel Jurnal .

Gestinawati, A., Iliyas, H., \& Manurung, I. (2016). Hubungan dukungan keluarga dengan kunjungan lansia ke posyandu. Jurnal keperawatan, volume.XII, No 2, Oktober 2016.

Hidayat, A. (2017). Hubungan aktivitas fisik dengan kualitas hidup lansia di posyandu desa selokarto kacamatan sempor kabupaten kebumen. gombong, 2017 .

Kamalie, h. s. (2016). Pengaru sense of belonging terhadap kualitas hidup lansia di panti wreda. universitas muhamadiyah malang .

Katuuk, M. E., Pinantoan, O. R., \& Samper, T. P. (2017). Hubungan intraksi sosial dengan kualitas hidup lansia di bplu senja cerah provinsi sulawesi utara. e-Journal Keperawatan (e-KP) Volume 5 Nomor 1, Februari 2017.

Lestari, D. R., Herawati, \& Waroh, S. (2016). Dukungan keluarga dengan kualitas hidup lansia di budi sejatra. Dunia Keperawatan, Volume 4, Nomor 1, Maret 2016: 65-60.

Mario. (2014). Hubungaan intraksi sosial dengan kualitas hidup lansia di bplu senja cerah provinsi sulawesi utara. e-Journal Keperawatan (e-KP) Volume 3 Nomor 1 , Februari 2014.

Mewengkang, y. d., Sekeon, S. A., \& Kaunang, W. P. (2017). Gambaran kualitas hidup pada lansia dengan hipertensi di kelurahan kolongan kacamatan tomohon tengah kota tomohon tahun 2017. Pakultas kesehatan masyarakat universitas sam patulang.

Padila, 2. (2015). Skripsi hubungan dukungan keluarga dengan kejadian depresi pada lansia. Sunday, November 1, 2015.

Puspita, P. G. (2016). Pengaru aktifitas jalan kaki terhadap kualitas hidup lanjut usia tidak terlatih di desa jururejo ngawi Universitas muhammadiyah surakatrta. Naska Publikasi ilmiah.

Putri, S. T. (2013). Kualitas hidup lansia yang tinggal bersama keluarga dan panti.Studi Keperawatan FPOK Universitas Pendidikan Indonesia 2013.

Rohma, A. I., Purwaningsi, \& Bariyah, K. (2012). Kualitas hidup lanjut usia.jurnal keperawatan, issn 2086-3071.

Rosdianti. (2015). Gambaran kualitas hidup lansia dengan hipertensi di wilayah kerja puskesmas rendang pada periode 27 februari sampai 14 maret 2015. Depertemen kesehatan 2015 .

Salim, o. c., Sudharma, N. L., Kusumaratna, R. K., \& Hidayat, A. (2007). Paliditas dan reliabilitas word health organisationnal quality of life-briref untuk mengukur kualitas hidup lanjut usia. Jurnal Mare 2016.

Sari, D. T. (2017). Hubungan indeks makan sehat dengan kualitas hidup lansia penderita hipertensi di wilayah puskesmas dadapayam kecamatan suruh kabupaten semarang. Surakarta, 8 juni 2017 . 


\section{COMPRBABDSIVEHAHW CARE}

Sari, M. k. (2016). Peningkatan kualitas hidup lansia mengunakan reminiscence affirmative therpy berbasis teori lazar. Jurnal Ners Lentera, Vol. 4, No. 1, Maret 2016 .

Sari, M. K., \& Yulia, P. (2017). Mindfullness Dengan Kualitas Hidup Pada Lanjut Usia. Jurnal Psikologi, Volume 10 Nomor 3, Juni 2017.

Sekarsari, R. (2017). Hubungan antara Persepsi Dukungan Sosial dan Kualitas Hidup Lansia dengan Hipertensi di Kota Tangerang.Jurnal Ilmiah Keperawatan Indonesia Vol 1, No 1, 2017 ISSN: 2580-3077.

Syamsuddin, et.al.,\& dkk, (2015). Pedoman Praktis Metodologi Penelitian Internal : Pendekatan Kualitatif, Kuantitatif, Pengembangan Dan Mix-Method, Wade Group : Ponorogo.

Sugiyono \& dkk, (2012). Metodologi penelitian kualitatif dan kuantitatif dalam bidang kesehatan.Alfabeta Bandung.

Tamber, S \& dkk, (2012). Kesehatan Usia Lanjut dengan Pendekatan Asuhan Keperawatan. Jakarta: Selemba Medika.

Triani, s. d. (2017). Hubungan indeks makan sehat dengan kualitas hidup lansia penderita hipertensi di wilaya kerja puskesmas dadapayam kacamatan suru kabupaten semarang.Surakarta 8 maret 2017.

Ummah. (2016). Hubungan kebutuhan spritual dengan kualitas hidup.Jurusan Keperawatan Fakultas Kedokteran Universitas Diponegoro Skripsi, Juli 2016.

KNEPK.(2012). EtikaPenelitian.

Wafroh, S., Herawati, \& Lestari, D. R. (2016). Dukungan keluarga dengan kualitas hidup lansia di pstw budi sejatera banjarbaru.Dunia Keperawatan, Volume 4, Nomor 1, Maret 2016: 60-64.

Wikananda,G, 2015. Hubungan kualitas hidup dan faktor resiko pada usia lanjut di wilaya kerja puskesmas tampaksiring 1 Kabupaten Gianyar Bali 2015. Di Rectory of open Access Jurnals, Gianyar Bali 2015.

Winahyu, K. M. (2017). Hubungan antara Persepsi Dukungan Sosial dan Kualitas Hidup Lansia dengan Hipertensi di Kota Tangerang.Jurnal Ilmiah Keperawatan Indonesia Vol 1, No 1, 2017 ISSN: 2580-3077 